\title{
Suicide Ideation During the COVID-19 Pandemic
}

\author{
Kashif Ali ${ }^{1}$ and Mohd Kaleem Khan ${ }^{2}$ \\ ${ }^{1}$ Senior Resident, Department of Forensic Medicine, Jawaharlal Nehru Medical College, India \\ ${ }^{2}$ Associate Professor, Department of Forensic Medicine, Jawaharlal Nehru Medical College, India
}

Submission: March 12, 2021; Published: March 23, 2021

*Corresponding author: Mohd Kaleem Khan, Associate Professor, Department of Forensic Medicine, Jawaharlal Nehru Medical College, AMU, Aligarh, Uttar Pradesh, India

Keywords: pneumonia; Psychotherapy; Coronavirus; Suicide; COVID lockdown.

\section{Introduction}

A major outbreak of pneumonia-like disease was first reported in the city of Wuhan in Hubei Province, China, in December 2019 [1]. The global spread of the disease happened rapidly around the world, causing a life-threatening disease called Coronavirus disease 2019 (Covid-19) named by the World Health Organization (WHO) in January 2020 [2]. The Covid-19 outbreak was declared by the WHO as a global public health emergency of international concern (PHEIC) on 11 March 2020 [1]. Online news media reports of 369 cases of suicides and attempted suicides during COVID lockdown vs 220 reports in 2019, a 67.7\% increase in suicidal behavior [3].

Poor health care infrastructure can cause concern in densely populated countries such as India and a certain level of panic remains in the population due to inadequate health protection measures around the world [4]. Covid-19 has had a profound impact on the world's population regardless of gender, age, functional differences (normal or disabled) and has created significant economic, psychological and social impacts worldwide [5,6]. In March and April 2020, the first COVID-19-related suicide cases were reported in India and Bangladesh in which two men who feared for their lives committed suicide [7]. The majority of reported victims were adult men as compared to women $[8,9]$. Viral outbreaks appear to be associated with psychiatric and psychological events (e.g., fear of infection, stigma of being diagnosed with a virus, cancellation of "non-emergency" hospitalizations) that may increase the risk of suicidal ideation and suicide attempts.

The social distancing and quarantine measures that have been enacted to curb the spread of the disease have resulted in increased loneliness, anxiety, stress, and depression in the general population. Virus exhibits neurotrophic properties and can cause serious neurological damage and disorders (e.g., toxic infectious encephalopathy) that can cause mental disorders [10]. In some cases, a viral infection can cause confusion, dysphoria, disorientation, and delirium, leading to suicidal ideation and behavior [11]. COVID-19, caused by the novel coronavirus SARSCoV-2, has infected more than 118 million people worldwide and $2,662,137$ have been died [12].

\section{Factors Associated with Suicidal Behaviors}

i. Fear of getting infection.

ii. Social isolation

iii. Relapse of mental illnesses

iv. Concern of being a burden on family.

v. Economic downturn

vi. Domestic and spousal disharmony.

\section{Preventive Measurements}

The WHO recommends not to monitor the continuous stream of news which exacerbates stress and there should be specific timing of news updates [13]. The most important measures to improve mental health are as follows-

i. Regular exercise, Balanced nutrition and Proper sleep.

ii. Maintain a strong family bond and Enhanced attention and surveillance. 
iii. Mental health screening and proper support and Psychotherapy via video-conference.

iv. Regular monitoring of depression, anxiety, posttraumatic stress symptoms, psychotic symptoms and suicidal thoughts.

v. Ensuring the delivery of essential services hassle-free for the elderly, disabled and those quarantined.

\section{Conclusion}

The pandemic of COVID-19 is a threat to the mental wellbeing of most and is a suicidal risk for some. This is a high time to make suicide prevention a major public health concern. There is an urgent need for mental health policies to be applied by various organizations depending on epidemic conditions. The Covid-19 induced suicide is preventable and research should be encouraged in these areas.

\section{Conflict of Interest: None.}

\section{References}

1. Sohrabi C, Alsafi Z, O'Neill N (2020) World Health Organization declares global emergency: a review of the 2019 novel coronavirus (COVID-19). Int J Surg 76: 71-76.

2. Zhang $\mathrm{W}$, Zhao Y, Zhang $\mathrm{F}$ (2020) The use of anti-inflammatory drugs in the treatment of people with severe corona virus disease 2019 (COVID-19): the experience of clinical immunologists from China. Clin Immunol 214: 108393.
3. Soumitra Pathare, Lakshmi Vijayakumar, Tanya Nicole Fernandes (2020) Analysis of news media reports of suicides and attempted suicides during the COVID-19 lockdown in India. International Journal of Mental Health Systems 14: 88.

4. Roy D, Tripathy S, Kar SK (2020) Study of knowledge, attitude, anxiety \& perceived mental healthcare need in Indian population during COVID-19 pandemic. Asian J Psychiatr 51:102083.

5. Mamun MA, Griffiths MD (2020) First COVID-19 suicide case in Bangladesh due to fear of COVID-19 and xenophobia: possible suicide prevention strategies. Asian J Psychiatr 51: 102073.

6. Usman N, Mamun MA, Ullah I (2020) COVID-19 infection risk in Pakistani healthcare workers: the cost-effective safety measures for developing countries. Social Health Behav 3: 75-77.

7. Goyal K, Chauhan P, Chhikara K, Gupta P, Singh MP (2020) Fear of COVID 2019: first suicidal case in India. Asian J Psychiatr 49: 101989.

8. Deena Dimple Dsouza, Shalini Quadros, Zainab (2020) Aggregated COVID-19 suicide incidences in India: Fear of COVID-19 infection is the prominent causative factor. Psychiatry Research 290: 113145.

9. Ravi Philip Rajkumar (2020) Suicides related to the COVID-19 outbreak in India: A pilot study of media reports; Asian J Psychiatr 53: 102196.

10. Toovey S (2008) Influenza-associated central nervous system dysfunction: a literature review. Travel Med Infect Dis 6: 114-124.

11. Severance EG, Dickerson FB, Viscidi RP, Bossis I, Stallings CR, et al. (2011) Corona virus immuno reactivity in individuals with arecent onset of psychotic symptoms. Schizophr Bull 37: 101-107.

12. Covid-19 Coronavirus Pandemic. Worldometer.

13. Mental health \& COVID-19 (2021) World Health Organization (WHO).

\section{Your next submission with Juniper Publishers will reach you the below assets}

- Quality Editorial service

- Swift Peer Review

- Reprints availability

- E-prints Service

- Manuscript Podcast for convenient understanding

- Global attainment for your research

- Manuscript accessibility in different formats

( Pdf, E-pub, Full Text, Audio)

- Unceasing customer service

Track the below URL for one-step submission https://juniperpublishers.com/online-submission.php 